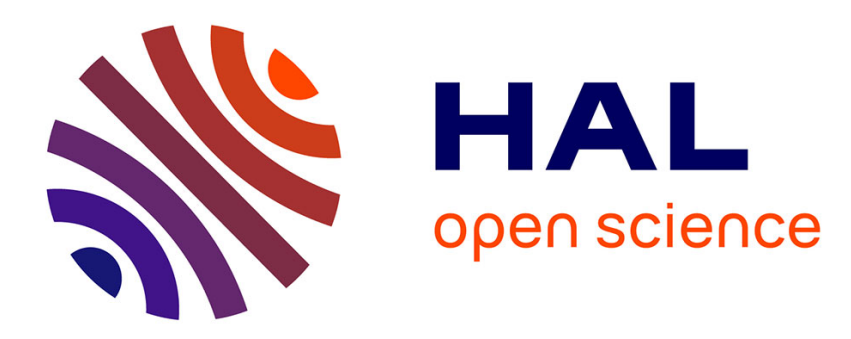

\title{
Strength of 10CR-N martensitic steels
}

F. Bahrami, A. Hendry

\section{To cite this version:}

F. Bahrami, A. Hendry. Strength of 10CR-N martensitic steels. Journal de Physique IV Proceedings, 1993, 03 (C7), pp.C7-97-C7-100. 10.1051/jp4:1993712 . jpa-00251738

\section{HAL Id: jpa-00251738 https://hal.science/jpa-00251738}

Submitted on 1 Jan 1993

HAL is a multi-disciplinary open access archive for the deposit and dissemination of scientific research documents, whether they are published or not. The documents may come from teaching and research institutions in France or abroad, or from public or private research centers.
L'archive ouverte pluridisciplinaire HAL, est destinée au dépôt et à la diffusion de documents scientifiques de niveau recherche, publiés ou non, émanant des établissements d'enseignement et de recherche français ou étrangers, des laboratoires publics ou privés. 


\title{
Strength of 10CR-N martensitic steels
}

\author{
F. BAHRAMI and A. HENDRY
}

Department of Metallurgy and Engineering Materials, 48 N. Portland Street, University of Strathclyde, Glasgow G1, U.K.

\begin{abstract}
Cr}$ stainless steel has been employed to examine the effect of nitrogen on microstructure and strength. Applying Solid state gaseous nitrogenising treatments a whole range of nitrogen martensite structures containing up to 0.45 wto were obtained. It was found that a linear relationship exists between strength and nitrogen content in precipitate free martensitic structures. Yield strength increased from 705 to $1295 \mathrm{MPa}$ for nitrogen free base material and alloys with 0.35 wto $\mathrm{N}$ respectively. Pronounce secondary hardening was observed at a tempering temperature of $500^{\circ} \mathrm{C}$. A linear relationship was also observed between the lattice parameter and nitrogen concentration in these alloys. A model for mechanical behaviour is presented.
\end{abstract}

MATERIAL AND EXPERIMENTS A commercial alloy was selected to examine the effect of nitrogen alloying in martensitic structures. The material examined was $33 \%$ cold rolled strip with $0.65 \mathrm{~mm}$ thickness and chemical composition of $0.016 \mathrm{C}, 0.002 \mathrm{~S}, 0.38 \mathrm{Si}$, $9.3 \mathrm{Cr}, 0.61 \mathrm{Mo}, 0.95 \mathrm{Ni}, 0.68 \mathrm{Mn}, 0.29 \mathrm{~V}$. By solid state nitrogenising and solution treatment at $1200^{\circ} \mathrm{C}$ nitrogen concentrations ranging from zero to 0.45 wt $\%$ were obtained. Tensile test samples with gauge length of $20 \mathrm{~mm}$ were punched from these strips. Tensile tests were carried out at temperatures from ambient up to $500^{\circ} \mathrm{C}$.

RESULTS AND DISCUSSION The Yield strength increases linearly with increasing nitrogen content (Figure 1 ) for steels cooled from solution treatment temperature. It is shown that this temperature is high enough to dissolve all nitrides [1], and upon cooling all nitrogen will be in solid solution in the lattice. Pronounced secondary hardening behaviour is observed by addition of vanadium and similar ferrite formers to 9-12\% Cr nitrogen alloyed materials $[1,2,3]$ and the results of hot strength tests shown in Figure 2 confirm this effect. Alloys tempered at $500^{\circ} \mathrm{C}$ retain the asquenched strength throughout the test temperature range. This is because of the locking effect of coherent precipitates and dislocation interaction.

Lattice parameter measurement for materials in the as quenched condition and tempered at $500^{\circ} \mathrm{C}$ is presented in Figure 3 . Both materials show a linear increase in lattice parameter by increasing nitrogen, with values of $0.0005 \mathrm{~nm} /$ at: $\mathrm{N}$ as quenched 
and $0.0003 \mathrm{~nm} /$ ats $\mathrm{N}$ after $500^{\circ} \mathrm{C}$ tempering. Thus in both conditions there is a contribution to strength by nitrogen in solid solution which is a maximum in the as quenched state and is combined with precipitates after $500^{\circ} \mathrm{C}$ tempering. TEM observation of dislocation networks and electron diffraction patterns [4] show that the strengthening mechanisms in these cases are governed by different mechanisms.

The dislocation glide mode in bcc metals is governed to a large extent by the relative mobilities of screw and non-screw (edge) dislocations. It is important to note that, whereas unstable dislocation propagation and multiplication can be facilitated at $\mathrm{T}>\mathrm{T}_{\mathrm{o}}$ (as in fcc metals), these processes are strongly impeded at $\mathrm{T}<\mathrm{T}_{0}$ because of the limited mobility of the screw dislocations, $T_{0}$ $\approx 0.1-0.3 \mathrm{~T}_{\mathrm{m}}$ (melting temperature). Nitrogen in solution causes certain problems, first distortion caused by occupation of sites, second the surrounding unoccupied sites attract the interstitial atom, causing high strain. By increasing interstitial atom concentration both these effects will increase. Occurrence of such distortion in the lattice will increase the peierls effect. Meanwhile tempering will result in reduction of lattice distortion while allowing dislocations to rearrange.

Linear regression analyses showed that the yield strength of this martensitic structure can be shown as follows:

$$
\mathrm{YS}=734+1681(\mathrm{~N})
$$

and similar linear behaviour has been observed for martensitic Csteel [5];

$$
\mathrm{YS}=535+2662 \text { (C) }
$$

The strengthening effect of carbon in as quenched plain carbon steel is generally higher than nitrogen in $10 \mathrm{Cr}$ steel and is mainly due to the higher specific strengthening effect of carbon than nitrogen [4] in martensite. However it appears that unlike the fresh martensite, strength and hardness of tempered $10-12 \mathrm{Cr}-\mathrm{N}$ alloys are greater than plain carbon and also $10-12 \mathrm{Cr}-\mathrm{C}$ alloys $[3,6,7]$ (Figure 4). This enhanced strength originates from sluggish precipitate formation and growth $[3,4]$. However it is worth mentioning that higher strength is the combined effect of dislocation interaction with cluster/coherent precipitates plus interaction with point defects as in solid solution strengthening. Finally an equation can be suggested according to the observed behaviour of martensite as follows:

$$
\sigma_{\mathrm{ps}}=\sigma_{\mathrm{isub}}+\sigma_{\mathrm{int}}+\sigma_{\mathrm{dis}}+\sigma_{\mathrm{ppt}}+\mathrm{Kd}^{-1 / 2}
$$

in which $\sigma_{p s}$ is the yield strength, $\sigma_{i}$ is the friction stress due to substitutional $\left(\sigma_{i s u b}\right)$ and interstitials $\left(\sigma_{i \text { int }}\right.$ ) alloying elements in solution, $\sigma_{\text {dis }}$ refers to the strengthening effect of dislocations, $\sigma_{\text {ppt }}$ refers to fine precipitation, which will add on to strength if the precipitates are not coarse, otherwise the effect will be negligible.

Contribution of o $\sigma_{i s u b} c a n$ be estimated by comparing the present results with existing data, and it is about $100 \mathrm{MPa}$. This value for a C-free maraging steels was determined to be $150 \mathrm{MPa}$. The contribution of $\sigma_{\text {dis }}$ is estimated to be not greater than $300 \mathrm{MPa}$ for carbon martensite $[5,8]$ and a similar value may be assumed for the present martensite considering the high dislocation density. $\sigma_{\mathrm{ppt}}$ can offer some strengthening effect, namely about 100 
Mpa. The contribution of the grain size is regarded to be about $200 \mathrm{MPa}$, independent of interstitial content.

The base nitrogen free martensite has a yield strength of $700 \mathrm{MPa}$ and the above parameters add to the strength giving the final strength of about $1500 \mathrm{MPa}$, from which it can be seen that the contribution from $\sigma_{i n t}$ is about $300 \mathrm{MPa}$. Quantitatively this in not very much more than the other terms, however it is also clear that the contribution of these other parameters also depend indirectly on interstitial content. For example in Figure 3 , the linear dependence of lattice parameter vs nitrogen content of the as-quenched material shows a similar lattice dilation with nitrogen content as given in the literature [9]. Thus for the material tempered at $500^{\circ} \mathrm{C}$ which has a smaller apparent dilation this can be interpreted as a fixed proportion of the nitrogen in precipitated form at each nitrogen level and from the difference in slope given above $30 / 53=60 \%$ of the nitrogen remains in solution and $40 \%$ is precipitated. The net effect on room temperature testing is that the latter case, with some precipitation, shows a higher strength than as-quenched (Figure 4) for all tempering temperatures up to $500^{\circ} \mathrm{C}$, above which coarsening of precipitation and recovery cause a strength decrease. It should be noted in Figure 2 however that at test temperatures above room temperature both as-quenched and $500^{\circ} \mathrm{C}$ temper behave similarly, since the duration of the test causes some precipitation in the as quenched alloy.

\section{REFERENCES}

1. F. Bahrami, K. Laing and A. Hendry; in Proc. Conf. on Materials for Advanced Technology Applications", 46,1991, Limerick, Edrs. M. Buggy and S. Hampshire, Trans. Tech. Pub., Vol. 72-74, 153, 1992 .

2. J. Foct, f. Vanderschaeve and R. Tailard; Proc. Conf., 4. Warmebehandlungstagung, March 1991, Chemnitz, Vol 15-1, 1991.

3. Berns $H$. and Krafft F, ; in" High nitrogen steels", proc. of HNS88, J. Foct and A. Hendry Eds., Inst. of Metals, London, $169,1989$.

4. F. Bahrami; PhD Thesis, University of Strathclyde, 1993.

5. W.C. Leslie; "The Physical Metallurgy of Steels", McGraw Hill, 1981 .

6. P.J. Uggowitzer and G. Stein; Proc. Conf., 1-3 Sep., 1987, Chicago, Illinoise, USA, R. Viswanathan and R.I. Jaffee edrs., ASM, 181, 1987.

7. B.R. Anthamatten et al; Conf. Proc. HNS 90, Stein G. and Witulski H. Eds., Dusseldorf, 436,1990 .

8. R.W.K. Honeycomb; "Steels, Microstructure and Properties", Arnold pub., 1981 .

9. A. Krawitz and R. Sinclair; Phil.Mag., 31, 697, 1975. 


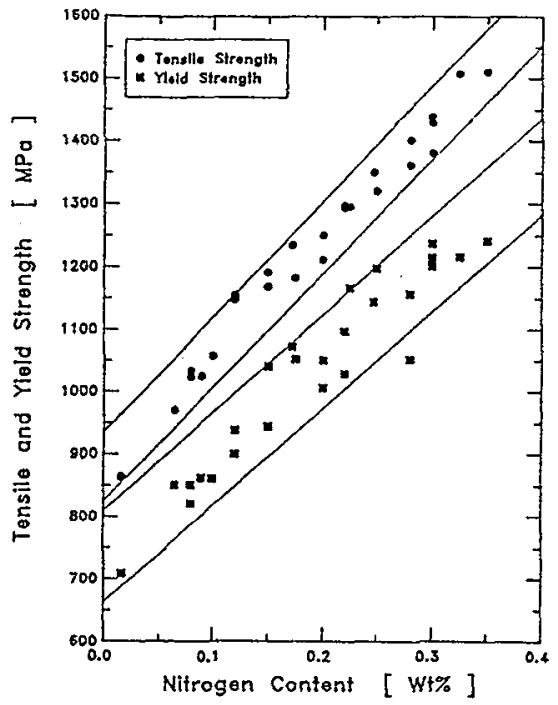

rigure 1 Tensile strength $\mathrm{Vs}$ nitrogen content in alloy $A$, solution treated ot $1200^{\circ} \mathrm{C}$.

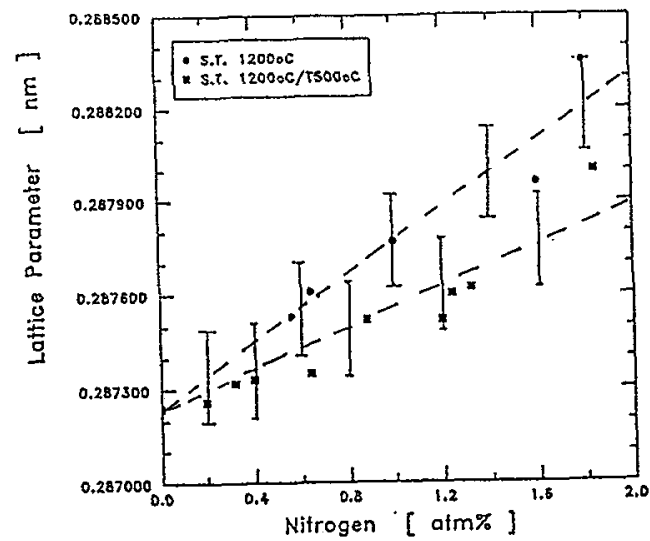

Figure 3 Latilce parameter relationship with nitrogen content, marteneite treated at $1200^{\circ} \mathrm{C}$.

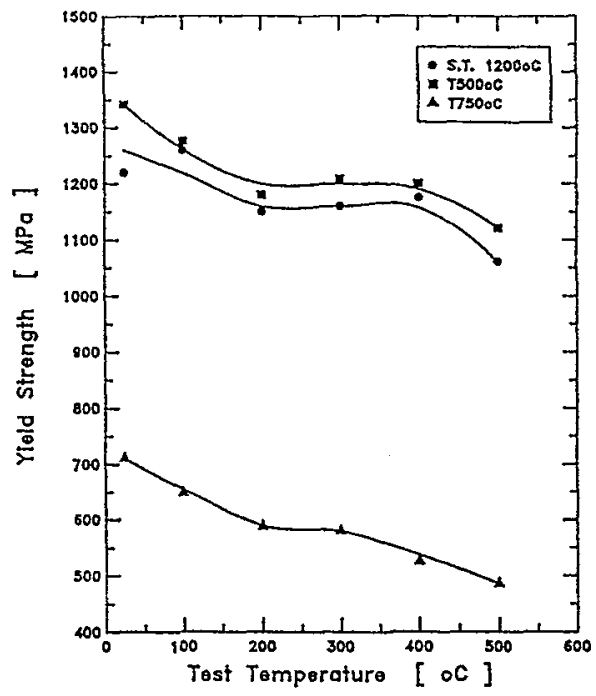

Figure 2 yleld strength Vis test temerature in alloy $A_{\text {, }}$

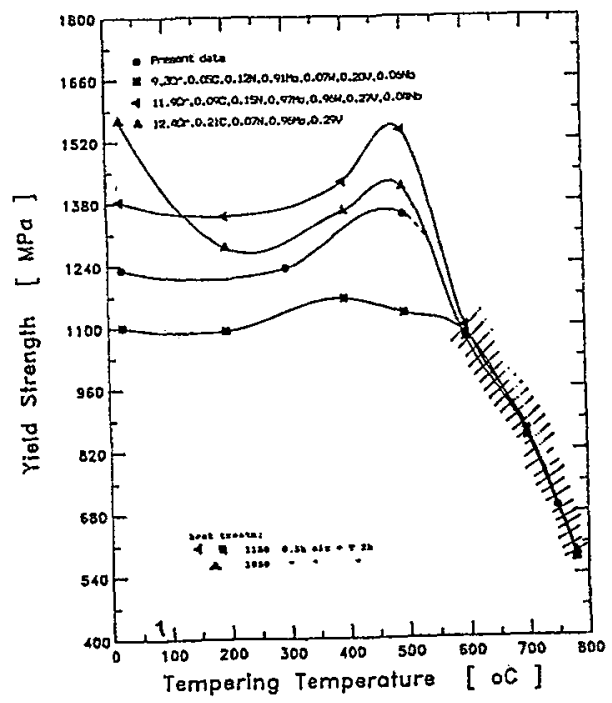

Figure 4 Yiejd strength ve teat temperature for comparable alloys. 